\title{
Reading Learning Strategies through Novel Review for the Student Characters Development
}

\author{
Rusma Noortyani \\ Indonesian Language Education Department \\ Faculty of Teacher Training and Education \\ Universitas Lambung Mangkurat \\ Banjarmasin, Indonesia \\ rusmanoortyani@ulm.ac.id
}

\begin{abstract}
This research is based on the results of students reading learning in reading learning theory course. This research aims to study the students reading learning through a novel review. The research method uses descriptive qualitative methods. This method is appropriate to use because the implementation of reading learning occurs naturally, as it is, and in normal situations by the circumstances and conditions of students of Indonesian Language Education Department. Research data are in the form of words, phrases, clauses, and sentences from 89 students who program reading learning theory course. Reading learning strategies for through novel reviews are conducted for one month - the data collected in the odd semester of the academic year 2017/2018 through involved observations guided by observation guides. Data analysis techniques including 1) data analysis, 2) data presentation, 3) verification and 4) conclusion. The results of the study are data in the form of 1) review of the title of the book, author, and novel pages, 2) a summary of all reading activities for two weeks, 3) a description of the effect of reading on the development of students character for two weeks, 4) a description of the plans and actions that will be carried out by students after obtaining the knowledge.
\end{abstract}

Keywords - reading learning strategies, novel reviews, character development

\section{INTRODUCTION}

The habit of reading books arises not because parents exemplify it, but because children are directly involved in reading activities. The involvement is related to the physical and emotional of the reader. According to reference [1], reading is a physical and mental activity that can develop into a habit. This involvement can foster reading habits. However, it must be done repeatedly and requires a considerable amount of time. Reference [1] states that reading habits are reading activities that have ingrained in a person (regarding society, habits are reading activities that have been entrenched in a society). Likewise with reference [2], arguing that when reading a book is required to repeat many times, a habit of reading will be formed. Reading habits will eventually lead to a fondness for reading. In other words, it can because it gets used to it. In line with Tampubolon's thinking in forming reading habits, two aspects that need to be considered are interested (a combination of desire, willingness, and motivation) and eye skills and mastery of reading techniques [3].
To motivate children to be interested in reading books, it can be done by involving them directly. If it only shows as an example, it will give little influence or not even exist. This can be interpreted as still very difficult to be interested in reading. Motivation to read will not be formed if the person does not have the desire, ideals or realize the benefits of reading for him. For this reason, certain conditions are needed, so that the reader or anyone who wants a passion for reading can be motivated. Reference [4] mentioned two things that need to be considered in increasing reading interest, namely providing time to read and choose good reading material.

The reading assignment can be applied to the initial step of familiarizing children with books. As long as the child can enjoy reading, that is the award obtained. Reading assignments can help put books as friends. The desire of parents began to foster understanding so that the book would become a friend. The book is quite enjoyed, and there should not be high expectations of reading activities. If a lot of material is remembered, of course, this is very good. However, if only a little, it doesn't matter. Reading activities are meant to be something valuable and fun. Reference [5] defines reading as processing words, concepts, information, and ideas put forward by authors that relate to the knowledge and initial experience of the reader. Reference [6] mentions three components in reading skills, namely: a) introduction to scripts and punctuation, b) literary relationships along with punctuation marks with formal linguistic elements. c) further relationships of $\mathrm{A}$ and $\mathrm{B}$ with meaning.

Reading is a method that can be used to communicate with ourselves and sometimes with others, that is to communicate the meaning contained or implied in written symbols. Reference [6] states that reading is a process that is carried out and used by the reader to get the message to be conveyed by the author through the medium of words or written language. The main purpose in reading is to find and obtain information, including content, understanding the meaning of reading. Reference [7] argues that the purpose of reading includes: a) understanding in detail and comprehensively the contents of the book; b) appropriately capture the main ideas or ideas; c) get information about something; d) recognize the meaning of words.

Reference [8] stated that the ability to read is the ability to see and understand the contents of what is written by 
expressing or only in the heart. The ability to read can be improved by mastering effective and efficient reading techniques. Various methods that can facilitate remembering the contents of the reading, namely 1) Question Read Recite Review Survey (SQ3R), 2) Survey Question Read Recite Rite Review (SQ4R), 3) Overview Key Ideas Read Summarize Test (OK4R), 4) Review Study Verbalize Preview (RSVP), 5) Purpose Overview Interpret Note Test (POINT), 6) Overview Ask Read Evaluate Test (OARWET), 7) Preview Question Read Summarize Test (PQRST), 8) Purpose Adaptability Need to Question Overview Read Annotate Memorize Access (PANORAMA), and 9) Explore Ask Read Tell Harvest (EARTH). The use of one of these methods can train children's reading skills. Children begin reading books for reading activities, enjoy reading activities so that the impression is finally embedded that the book is a friend to share time.

Reading can also be considered as a process to understand the implicit in the express, namely to understand the meaning contained in written words. The meaning of reading is not on the written page but in the reader's mind. Thus the meaning will change because each reader has different experiences that are used as tools to interpret the words.

Research on reading learning strategies has been researched by reference [9] entitled the learning strategy for integrated reading skills in Makassar junior high school 1. This study measures students' reading skills. The difference in reading strategies is applied because of the object of student research, while the current research is a strategy used for students. This research is based on the results of reading learning of students in the theory of reading learning subjects. This study aims to examine student reading learning through novel reviews. Therefore, it is very important to be implemented to obtain a description of the reading learning strategy through novel reviews for student character development.

\section{METHOD}

The research method uses descriptive qualitative research methods [10]. This method is appropriate to use because the implementation of reading learning occurs naturally, as it is, and in normal situations according to the conditions and conditions of students of the Indonesian Language Education Department. Research data are in the form of speech words, phrases, clauses, and sentences from students who program reading learning theory courses amounted to 89 people. The strategy of reading through the novel review is conducted for one month - data collected in the odd semester in academic year 2017/2018 through involved observation guided by observation guidelines. Data analysis techniques include 1) data analysis, 2) data presentation, 3) verification, and 4) conclusions [11].

\section{RESULTS AND DISCUSSION}

The reading assignments given to students have obtained novel identity data, synopsis, reviews, and vocabulary that are considered new by students. Here is a result of the assignment.

Book Title: Garis Waktu

Author: Fiersa Besari
Editor: Juliagar R. N.

Publisher: Media Kita

The print I: 2016

Language: Indonesia

ISBN : 978-979-794-525-1

Thick: 212 pages

Price: Rp58.000,-

Synopsis

On a time line that is crawling forward, there will be times when you meet one person who changes your life forever. On a time line that is crawling forward, there will be times when you get hurt and lose grip. On a time line that is crawling forward, there will be times when you want to jump back at certain points of memory. So, just be willing, then. Because really, what's more, painful than letting go is to hold on to something that hurts you slowly.

Garis Waktu is a collection of stories or summaries of writing made by Fiersa Besari. Fiersa Besari is an independent musician from Bandung which began its existence in the world of music in 2012 by launching an album titled "11:11" and then back to making an album in 2013 entitled "Tempat Aku Pulang" and the album "Konspirasi Alam Semesta" in 2015. However, on the Konspirasi Alam Semesta album, Fiersa made not only songs, but also an album and a book that is a fusion between literature and music, presenting stories about love.

Garis Waktu is the second book by Fiersa Besari which summarizes some of his writings in the 2012-2016 period. Fiersa Besari is a writer who is also active as a music player, motion capture, and natural activist. Previously, he had released a music album entitled Konspirasi Alam Semesta in 2015, which was later reborn in book form in April 2017 by Media Kita.

"Life is a series of coincidences. 'Incidentally 'is an undercover destiny.' (P. 9)

The book which contains a series of stories with the format of a collection of letters strung together into one outline contains an outline of the encounter, love, broken heart, sincerity in letting go and ending with memories. It is me, who describes his feelings for you in the form of letters from the first April to the fifth year of March. From the beginning of the meeting and face to face until no longer set each other. Short letters in the Timeline amount to 49 letters containing all my questions, anxieties, anger, and feelings for a woman who has made her fall in love and heartbroken. Two of them are a kind of prologue and epilogue.

From the 49 letters, there are two that I like; the letter in the first June of the second title invites (and perhaps also realizes) the reader to be themselves and the letter in September of the second year the first title which contains love and commitment. Overall there are three major chapters in the Garis Waktu, which are meetings with someone who changes lives, hurts and loses, and desires to return to certain desires. "To be honest, that is difficult. At least, be honest with yourself; do things that are truly desired by the conscience, even though they must be insulted by others. "(p. 27). "In our only one life, what is the need to waste time taking care of those who don't need to, judge what we don't know, and hostile to things we don't understand?" (P. 100) 
Readers will not only find messages about romance implied in the Garis Waktu, but also messages to be yourself, in establishing a relationship with someone, to enjoy life and take the time to do things we like because they live only once, not drowning in popularity, not replying to hatred with hatred, not dissolving in revenge, etc. Sometimes I feel jolted with a few sentences that he wrote: not annoying sentiment, but a reminder that reminds.

Garis Waktu brings us to explore the process as well as the times when I and You become us. Also Me and You who finally chose a different direction. Readers are invited to watch me who is a monologue. Seeing me waiting for a message from you, his hopes have vanished, filled with turmoil, full of admiration for you, still admiring even though he cannot have, harboring his feelings, being a place of escape, frank about his feelings, experiencing a betrayal, etc. "Because whether you are as far as the sky, or as close as the ceiling, to me you are a star that I adore." (P. 17). "Hidden love is the language of silence with a grasping heart." (P. 40)

First is very good at stirring up the feelings of the reader through the sentences that are passed on. As if he understood and knew the reader. The sentences he wrote felt alive and very representative of someone who, both in love, upset, broken hearted, hurt by being betrayed, and able to rise from the bitter things that happened to him. Even though we know the things that I experienced must have also been experienced by other people, the way each person gets up and heals his wound is not the same. Through Garis Waktu, the reader can take lessons from experience and what was conveyed by me.
When compared to the Konspirasi Alam Semesta, Garis Waktu can be said to have a different concept, and the plot is only one plot; chronological plot. The disadvantage is that advanced paths like this for some readers might be boring. I feel this book is less interesting because the plot seems flat. Once upon a time makes boredom come. It could also be because I've read the writings, such as on Twitter, Instagram or LINE. Interestingly, in each letter, there are photographs that illustrate the outpouring of the Me that allows the reader to simultaneously play his imagination.

Here's the vocabulary in the novel that is considered new by Indonesian Language Education students.

- constellation: a set of people, properties, or related objects

- stagnation: stalled

- included: written, listed

- consortium: set, collection

- sporadic: uncertain

Furthermore, the results of the study found data in the form of 1) review of book titles, authors, and novel pages, 2) summary of all reading activities for two weeks, 3) description of the influence of reading on student character development for two weeks, 4) description of plans and actions what students will do after getting this knowledge. The following are ten results of reading assignments and the influence of character development in Indonesian Language Education students.

TABLE I. THE REVIEW RESUlt OF NOVEL BOOK

\begin{tabular}{|c|c|c|c|}
\hline Novel Identity & $\begin{array}{c}\text { Novel Influence on Character } \\
\text { Development }\end{array}$ & Plans to be carried out & Actions to be carried out \\
\hline $\begin{array}{l}\text { Title: Hafalan Shalat Delisa } \\
\text { Author: Tere Liye } \\
\text { Publisher: Republika Penerbit } \\
\text { Publication Year: } 2008 \\
\text { Page: } 266 \text { pages }\end{array}$ & $\begin{array}{l}\text { The growth of religious character because } \\
\text { in the novel "Hafalan Sholat Delisa." } \\
\text { the exemplary portrayal of obedience in } \\
\text { carrying out the teachings of the religion } \\
\text { she adheres to, namely morning prayer } \\
\text { together, tadarus and spirit of learning } \\
\text { religion. } \\
\text { The growth of the character of tolerance } \\
\text { because in the novel "Hafalan Sholat } \\
\text { Delisa" there are attitudes and actions that } \\
\text { respect religious differences, between Koh } \\
\text { Acan and the family of Umi Salamah. }\end{array}$ & $\begin{array}{l}\text { More passionate about studying } \\
\text { religion. } \\
\text { More mature Muslim characters. } \\
\text { Pray on time. } \\
\text { Wants to form a religious and } \\
\text { harmonious family. }\end{array}$ & $\begin{array}{l}\text { Regularly studying religion on } \\
\text { social media, reading or in } \\
\text { assemblies. } \\
\text { Keep away from adultery which is } \\
\text { not dating so we can meet with the } \\
\text { figure of a priest who can form a } \\
\text { harmonious and religious family. } \\
\text { Invites friends to pray if already } \\
\text { entered prayer time when the call to } \\
\text { prayer is coming. } \\
\text { Slowly try to instill calm, patient } \\
\text { and sincere attitude. }\end{array}$ \\
\hline $\begin{array}{l}\text { Title: Garis Waktu } \\
\text { Author: Fiersa Besari } \\
\text { Publisher: Media Kita } \\
\text { Print: First } \\
\text { Publication Year: } 2016 \\
\text { Thick: } 212 \text { Pages }\end{array}$ & $\begin{array}{l}\text { Honest: Honest efforts to express feelings, } \\
\text { Hard work: Persistence in reaching goals, } \\
\text { Responsibility: } \\
\text { responsible for every promise he makes, } \\
\text { Love peace: } \\
\text { Acceptance when betrayed, } \\
\text { Befriend: } \\
\text { Receive gracefully when other people get } \\
\text { the woman he likes. }\end{array}$ & $\begin{array}{l}\text { Trying to take the character } \\
\text { development found in the book. }\end{array}$ & $\begin{array}{l}\text { Applying it in life, making the } \\
\text { mistake of I character as learning } \\
\text { for myself as an indirect experience } \\
\text { that comes from other people } \\
\text { sourced from a novel. }\end{array}$ \\
\hline $\begin{array}{l}\text { Title: Sebuah } \\
\text { Melupakan } \\
\text { Author: Boy Candra } \\
\text { Publisher: Media kita } \\
\text { City of publishers: South } \\
\text { Jakarta } \\
\text { Thick: } 306 \text { pages } \\
\text { Publication Year: } 2016 \\
\text { Type of book: Kumpulan }\end{array}$ & $\begin{array}{l}\text { The values of character development that I } \\
\text { get are in the form of honesty, hard work, } \\
\text { friendliness or communicative, peace- } \\
\text { loving, social care and responsibility. } \\
\text { The value of the hard work described by } \\
\text { my character at the same time illustrates } \\
\text { honesty when he tries to heal his own heart } \\
\text { by having to honestly accept the situation } \\
\text { and try hard to get back up. Although the I }\end{array}$ & $\begin{array}{l}\text { I am motivated to be a strong, honest } \\
\text { person, forgiving and a hard worker. } \\
\text { In this book, it teaches me that sadness } \\
\text { and disappointment do not have to be } \\
\text { spent with tears. Sadness can be a } \\
\text { motivation to work and make success } \\
\text { in life. I want to be a strong person, } \\
\text { not easily discouraged just because of } \\
\text { things that will hinder my success. I }\end{array}$ & $\begin{array}{l}\text { The thing I started doing to realize } \\
\text { my motivation after reading } \\
\text { this book is certainly instilled in my } \\
\text { heart and mind to be able to become } \\
\text { Better person. I also began to write } \\
\text { poems and collect it as a form of } \\
\text { my desire to be able to start } \\
\text { working. } \\
\text { I began to learn to look at various }\end{array}$ \\
\hline
\end{tabular}




\begin{tabular}{|c|c|c|c|}
\hline Novel Identity & $\begin{array}{c}\text { Novel Influence on Character } \\
\text { Development }\end{array}$ & Plans to be carried out & Actions to be carried out \\
\hline $\begin{array}{l}\text { Cerita (collection of stories) } \\
\text { ISBN: 978-979-794-520- } 6\end{array}$ & $\begin{array}{l}\text { character knows that his lover has chosen } \\
\text { another man and left him, he remains } \\
\text { patient and chooses to succumb to describe } \\
\text { the value of peace. } \\
\text { The communicative value that I get is that } \\
\text { everything must be explained and } \\
\text { communicated so that problems do not } \\
\text { arise due to misunderstanding. } \\
\text { The value of social care and responsibility } \\
\text { is also reflected in my character who } \\
\text { always thinks of the goodness of others } \\
\text { and is faithful as a form of responsibility to } \\
\text { carry out the commitments that have been } \\
\text { built with his lover. }\end{array}$ & $\begin{array}{l}\text { want to uphold honesty in life and } \\
\text { remain a good and forgiving person. } \\
\text { This book also teaches me that nothing } \\
\text { is impossible when we try hard, } \\
\text { including to drive away sadness and } \\
\text { rediscover happiness. }\end{array}$ & $\begin{array}{l}\text { shortcomings in myself and still had } \\
\text { to learn to improve myself. This is } \\
\text { one of them so that I can be } \\
\text { easier forgive someone else's } \\
\text { mistakes when I can realize that } \\
\text { there is nothing Perfectly created } \\
\text { humans. I also began to learn to be } \\
\text { grateful for life } \\
\text { I can be a strong person by } \\
\text { continuing to be grateful, so it is not } \\
\text { easy lisction in } \\
\text { discouraged and lost direction } \\
\text { living life. }\end{array}$ \\
\hline $\begin{array}{l}\text { Title: Catatan Pendek Untuk } \\
\text { Cinta Panjang } \\
\text { Author: Boy Candra } \\
\text { Publication Year: January } 2015 \\
\text { Number of pages: } 212 \text { pages } \\
\text { Book weight: } 250 \text { grams }\end{array}$ & $\begin{array}{l}\text { The influence on personal character } \\
\text { development, namely tolerance, and } \\
\text { honesty. Because it is in one of the grooves } \\
\text { which states "the woman prefers to } \\
\text { maintain her relationship with her lover, } \\
\text { rather than moving his heart to his best } \\
\text { friend." She chooses to be honest with his } \\
\text { lover. } \\
\text { Also, the value of tolerance can be seen in } \\
\text { the plot when one of the figures succumbs } \\
\text { to determining the event they are visiting, } \\
\text { namely a bookstore or poetry performance. }\end{array}$ & $\begin{array}{l}\text { I want to be a person who is honest } \\
\text { and has a high tolerance, to have a } \\
\text { good relationship with others and the } \\
\text { environment. }\end{array}$ & $\begin{array}{l}\text { I want to develop myself in } \\
\text { behaving honestly and increasing } \\
\text { tolerance, by applying honest } \\
\text { behavior in every word and deed in } \\
\text { life. Besides that, I learned to } \\
\text { tolerate respect for differences of } \\
\text { opinion and purpose. }\end{array}$ \\
\hline $\begin{array}{l}\text { Title: Rembulan } \\
\text { Tenggelam Di } \\
\text { Wajahmu } \\
\text { Author: Tere Liye } \\
\text { Publisher: PT Gramedia, } \\
\text { Jakarta } \\
\text { Print: VI } \\
\text { Thick: } 426 \text { pages } \\
\text { Price: Rp } 60.000\end{array}$ & $\begin{array}{l}\text { Being sincere and able to accept the reality } \\
\text { of all the tests given by God. } \\
\text { Make us able to be grateful in all } \\
\text { circumstances. Instill that we cannot be } \\
\text { vindictive people. }\end{array}$ & $\begin{array}{l}\text { After reading this novel, we become } \\
\text { motivated to move in a better } \\
\text { direction. The story in the novel } \\
\text { directs our personality to be able to } \\
\text { interpret sincerity, be grateful, and not } \\
\text { harbor hate so that the next plan is to } \\
\text { form a person who can take lessons } \\
\text { from the novel that is read and apply it } \\
\text { in life. }\end{array}$ & $\begin{array}{l}\text { Thankful in every situation. } \\
\text { Sincere and able to accept reality. } \\
\text { Not revenge against fellow human } \\
\text { beings. }\end{array}$ \\
\hline $\begin{array}{l}\text { Title: Daun Yang } \\
\text { Jatuh Tidak Pernah } \\
\text { Membenci Angin } \\
\text { Author: Tere Liye } \\
\text { Publisher: PT } \\
\text { Gramedia Pustaka } \\
\text { Utama } \\
\text { Publication year: } 2018 \\
\text { The number of pages: } \\
264 \text { pages }\end{array}$ & $\begin{array}{l}\text { This novel can develop an attitude of } \\
\text { helping others regardless of who is being } \\
\text { helped. } \\
\text { Be optimistic and never give up in living } \\
\text { life despite many obstacles that hinder it. } \\
\text { Devote to parents regardless of the } \\
\text { conditions of our parents. } \\
\text { Very diligent in learning so that dreams } \\
\text { can be achieved }\end{array}$ & $\begin{array}{l}\text { I plan to never give up on living } \\
\text { because we don't know what will } \\
\text { happen in the future. }\end{array}$ & $\begin{array}{l}\text { a. Be helpful to others. } \\
\text { b. Patient in living life } \\
\text { c. Optimistic } \\
\text { d. Honest } \\
\text { e. Loyal to both parents }\end{array}$ \\
\hline $\begin{array}{l}\text { Title: Hujan } \\
\text { Author: Tere Liye } \\
\text { Publisher: Gramedia Pustaka } \\
\text { Utama } \\
\text { Publication year: } 2016 \\
\text { Page: } 320 \text { pages }\end{array}$ & $\begin{array}{l}\text { a. Make students aware of God's power } \\
\text { that is greater than anything } \\
\text { b. Making students understand the } \\
\text { importance of honesty in doing various } \\
\text { things } \\
\text { c. Do not discriminate between friends } \\
\text { both physically and from other aspects } \\
\text { d. Awaken students to the importance of } \\
\text { discipline and hard work in doing } \\
\text { things } \\
\text { e. Awaken students to be independent in } \\
\text { determining various choices in this life } \\
\text { f. Making students have a high mindset } \\
\text { g. Make students able to imagine broadly } \\
\text { h. Making students enthusiastic about } \\
\text { reading } \\
\text { i. Have the spirit to live life } \\
\text { j. Receive everything that happens in this } \\
\text { life }\end{array}$ & $\begin{array}{l}\text { a. Will try to realize important } \\
\text { lessons obtained in real life } \\
\text { b. Will try to convey important } \\
\text { lessons contained in the book to } \\
\text { others }\end{array}$ & $\begin{array}{l}\text { a. Applying some essential } \\
\text { messages contained in the book } \\
\text { into real life. } \\
\text { b. Tells the contents of the book to } \\
\text { friends so that friends are also } \\
\text { able to know the results of our } \\
\text { reading and can take important } \\
\text { messages contained in the books } \\
\text { we read. }\end{array}$ \\
\hline $\begin{array}{l}\text { Title: Pada Senja yang } \\
\text { Membawamu Pergi } \\
\text { Author: Boy Chandra } \\
\text { Publisher: Gagas Media } \\
\text { Publication year: } 2016\end{array}$ & $\begin{array}{l}\text { a. Hard Work, in this novel the author } \\
\text { describes how the main character has a } \\
\text { very high nature of hard work } \\
\text { b. Independent, the figure in this novel is } \\
\text { said to be a very independent overseas }\end{array}$ & $\begin{array}{l}\text { a. I became motivated always to } \\
\text { work hard } \\
\text { b. I will be an independent individual } \\
\text { and not dependent on others } \\
\text { c. I will add more love to my country }\end{array}$ & $\begin{array}{l}\text { a. I always work hard to achieve } \\
\text { something I want } \\
\text { b. I am no longer a spoiled person } \\
\text { c. My love for the country is } \\
\text { increasing }\end{array}$ \\
\hline
\end{tabular}




\begin{tabular}{|c|c|c|c|}
\hline Novel Identity & $\begin{array}{c}\text { Novel Influence on Character } \\
\text { Development }\end{array}$ & Plans to be carried out & Actions to be carried out \\
\hline Thick: 245 pages & $\begin{array}{l}\text { student } \\
\text { c. Love the country; the story upholds the } \\
\text { love of the country by the author }\end{array}$ & to this nation & \\
\hline $\begin{array}{l}\text { Title: Konspirasi Alam } \\
\text { Semesta } \\
\text { Author: Fiersa Besari } \\
\text { Publisher: Media Kita } \\
\text { Publication year: } 2017\end{array}$ & $\begin{array}{l}\text { a. Honesty, honesty is fundamental in life } \\
\text { because, with honesty, every problem } \\
\text { must be a way out or a solution. } \\
\text { b. Hard Work and Independent, in this } \\
\text { novel the author, tells the Juang figure } \\
\text { that able to succeed with his efforts } \\
\text { and hard work to produce } \\
\text { extraordinary results without any } \\
\text { interference from parents or other } \\
\text { people. } \\
\text { c. Love the country, care for the } \\
\text { environment and social, this novel tells } \\
\text { how the character Juang love his } \\
\text { county and its natural beauty, this is } \\
\text { exemplary for today's youth especially } \\
\text { for me. } \\
\text { d. Responsibility, if we have chosen or } \\
\text { decided something should be } \\
\text { consistent and responsible. }\end{array}$ & $\begin{array}{l}\text { Everything that we experience or we } \\
\text { see must be a new experience and } \\
\text { become a benchmark to mature } \\
\text { ourselves by learning what happened. } \\
\text { Similarly, reading something will } \\
\text { change the previous thinking pattern to } \\
\text { be better or worse. } \\
\text { After reading this novel, I hope that I } \\
\text { will be able to become a person who is } \\
\text { more sensitive to the environment and } \\
\text { the feelings of others, interpret life } \\
\text { more broadly, and be more responsible } \\
\text { in carrying out things. }\end{array}$ & $\begin{array}{l}\text { To realize what I have planned after } \\
\text { reading a novel with an existing } \\
\text { moral message, I will try to improve } \\
\text { what must be improved in myself, } \\
\text { try to get to know myself, develop } \\
\text { what should be developed such as } \\
\text { talents, hobbies, and others. } \\
\text { Change your mindset and keep } \\
\text { thinking positively. }\end{array}$ \\
\hline $\begin{array}{l}\text { Title: Surat Kecil Untuk Ayah } \\
\text { (Revised Edition) } \\
\text { ISBN Number: } \\
9786022202561 \\
\text { Author: Boy Candra } \\
\text { Publisher: PT Bukune Kreatif } \\
\text { Cipta } \\
\text { City of publishers: Ciganjur- } \\
\text { Jagakarsa } \\
\text { Publication Year: January } 2018 \\
\text { Thick: } 174 \text { Pages }\end{array}$ & $\begin{array}{l}\text { Makes me more understand that parents } \\
\text { have struggled to fight for their family life, } \\
\text { more understand how much parents } \\
\text { sacrifice for their children in fulfilling their } \\
\text { daily needs, more understand that parents' } \\
\text { love is more than anything else. This } \\
\text { makes me always grateful for what they } \\
\text { give me, always grateful if God always } \\
\text { gives them health, and makes me even } \\
\text { more active in learning so that they are } \\
\text { proud and very happy if I become a great } \\
\text { person with the success that I get. }\end{array}$ & $\begin{array}{l}\text { I will try to realize all the positive } \\
\text { aspects contained in the novel, one of } \\
\text { them is to make my parents happy by } \\
\text { realizing their desires, trying not to } \\
\text { make them disappointed and sad. }\end{array}$ & $\begin{array}{l}\text { Will be as much as possible to love, } \\
\text { help, be grateful, happy, and always } \\
\text { do the best for my parents. } \\
\text { Will prioritize the interests of } \\
\text { parents first. }\end{array}$ \\
\hline
\end{tabular}

\section{CONCLUSION AND SUGGESTIONS}

The reading learning strategies through novel review undertaken by Indonesian Language Education Study Department students ULM influences character development, namely religious, honest, hard work, responsibility, peace of mind, social care, tolerance, help, dedication to parents, discipline, hard work, independent, and love the homeland. The plans and actions that students will take after reading the novel are very realistic. Character education can be used as a catalyst or filter to stem the outbreak of a culture of violence. Learning good values balanced with intensive habituation patterns can lead students to behave and behave according to noble values.

Suggestions in this study related to student reading habits to be improved, so that they have good reading skills. The habit of reading students supported by efforts by paying attention to facilities that can support, such as increasing the number of collections of novels, both in the reading room of Indonesian Language Education Study Department and in the ULM Library. This is important to trigger the enthusiasm and motivation of students to read to form a reading culture.

\section{REFERENCES}

[1] D. P. Tampubolon, Mengembangkan Minat dan Kebiasaan Membaca pada Anak. Bandung: Angkasa, 1986.

[2] D. K. Sukardi, Bimbingan Perkembangan Jiwa Anak. Jakarta: Ghalia Indonesia, 1987.

[3] D. P. Tampubolon, Kemampuan Membaca Teknik Membaca Efektif dan Efisien. Bandung: Angkasa, 1987.

[4] P. J. Farris, Language Arts. A Process Approach. Melbourne: Brown \& Benchmark Publishing, 1993.

[5] H. G. Tarigan, Membaca sebagai Suatu Keterampilan Berbahasa. Bandung: Angkasa, 1979.

[6] Nurhadi, Bagaimana Meningkatkan Kemampuan Membaca. Bandung: CV Sinar Baru, 1989

[7] Y. Mulyati, Membaca. Jakarta: Cipta Karya, 1997.

[8] Hasrianti, "Strategi pembelajaran keterampilan membaca secara terpadu di SMP Negeri 1 Makassar,” Jurnal Media, vol. 1, no 2.

[9] R. C. Bogdan, S. K. Biklen. Qualitative Research for Education: An Introduction to Theory and Methods. Boston: Allyn and Bacon Inc, 1998.

[10] M. B. Miles, A. M. Huberman, Qualitative Data Analysis. London: Sage Publication, 1984.

[11] H. G. Tarigan, Membaca Ekspresif. Bandung: Angkasa, 1987. 